\title{
Amiodarone compared with iodine exhibits a potent and persistent inhibitory effect on TSH-stimulated cAMP production in vitro: a possible mechanism to explain amiodarone-induced hypothyroidism
}

Vicki Pitsiavas, Peter Smerdely and Steven C Boyages

Departments of Diabetes and Endocrinology and Laboratory Endocrinology, Westmead Hospital, Westmead, New South Wales, Australia 2145

(Correspondence should be addressed to Vicki Pitsiavas, Laboratory Endocrinology, ICPMR, Westmead Hospital, Westmead, New South Wales, Australia 2145)

\begin{abstract}
Amiodarone (AMD) is a powerful anti-arrhythmic drug used for the treatment of a wide variety of cardiac arrhythmias and its most striking feature is its high iodine content. Thyroid dysfunction is a limiting side-effect of the drug and both AMD-induced hypothyroidism (AIH) and AMD-induced thyrotoxicosis (AIT) are reported. To examine the hypothesis that altered bioavailability of iodine is a contributing event in the pathogenesis of $\mathrm{AIH}$, we compared the effects of AMD and inorganic iodine in vitro on events involved in the process of thyroid autoregulation. FRTL- 5 cells and JP2 6 CHO cells (transfected with the human TSH receptor) were exposed to AMD or NaI in the presence of TSH, and cAMP production was measured as an indicator of cellular function. Forskolin and cholera toxin were also used to determine the possible target sites of AMD and iodide. Our results indicated that there was a difference between the effects of AMD versus those of physiological doses of iodide. The inhibitory effects of AMD occurred at lower concentrations of iodide than those seen in the NaI-treated cells. The effects of AMD were irreversible indicating a possible persistence of the Wolff-Chaikoff effect due to a constant high intracellular iodide level. The inhibitory effects of AMD (also seen at supraphysiological doses of iodide) were partially overcome by forskolin but not by cholera toxin indicating an effect on TSH receptor interactions with the other signal transduction elements such as G proteins and adenylate cyclase. The persistence of the Wolff-Chaikoff effect through loss of autoregulation may be a mechanism of the observed hypothyroidism in some patients taking AMD. The combined effects of the constant release of iodide together with the drug toxicity may be the mechanism for the observed effects.
\end{abstract}

European Journal of Endocrinology 140 241-249

\section{Introduction}

Amiodarone (AMD) is a powerful anti-arrhythmic drug used for the treatment of a wide variety of cardiac arrhythmias and its most striking feature is its high iodine content (1). The two atoms of iodine per AMD molecule make up approximately one-third of its molecular weight, resulting in roughly 40 times the average daily requirement of iodine released per $200 \mathrm{mg}$ tablet (2). Thyroid dysfunction is a limiting side-effect of the drug and both AMD-induced hypothyroidism (AIH) and AMD-induced thyrotoxicosis (AIT) are reported. The pathophysiological mechanisms of both AIH and AIT are poorly understood.

AIH is commonly explained as a failure of the thyroid gland to escape from the Wolff-Chaikoff effect by the release of stored iodine resulting in permanent inhibition of organification. In general, the commonest conditions for a failure to 'escape' from an iodine load are immaturity of the thyroid gland, the presence of thyroid autoimmunity or genetic abnormalities of thyroid hormone synthesis. Specifically, in patients with AIH, pre-existing thyroid autoimmunity has been found to be a strong predictor of persistent hypothyroidism $(3,4)$. This failure to autoregulate iodine in states of thyroid autoimmunity may be exacerbated by the increased bioavailability of iodine from AMD. Because of its highly lipophilic nature, AMD, and therefore iodine, directly enters the cytoplasm of the thyroid cell, bypassing the normal iodide transporter pathway. Rani (5), using dog thyroid slices, showed that AMD irreversibly inhibited thyrotrophin (TSH)-stimulated cAMP generation in the intact thyroid cell and this inhibition was lost in membrane preparations alone. To examine the hypothesis that altered bioavailability of iodine is a contributing event in the pathogenesis of 
AIH, we compared the effects of AMD and inorganic iodine in vitro on events involved in the processes of thyroid autoregulation.

\section{Materials and methods}

\section{Cell culture techniques}

FRTL-5 cells This thyroid cell line is derived from Fisher rat thyroids and has an obligate requirement for TSH for growth in cell culture. Further, FRTL- 5 cells express a differentiated cell phenotype through the presence and regulation of thyroglobulin, cAMP production and iodine uptake (6-8).

FRTL-5 cells were a gift from Dr L Kohn (Bethesda, MD, USA) by way of the laboratories of Dr H Drexhage (Amsterdam, The Netherlands). FRTL-5 cells were routinely cultured in $75 \mathrm{~cm}^{2}$ flasks in Coons' modified F-12 medium containing insulin $(10 \mu \mathrm{g} / \mathrm{ml})$, hydrocortisone $(0.32 \mathrm{ng} / \mathrm{ml})$, transferrin $(5 \mu \mathrm{g} / \mathrm{ml})$, glycyl-Lhistidyl-L-lysine $(10 \mathrm{ng} / \mathrm{ml})$, somatostatin $(10 \mathrm{ng} / \mathrm{ml})$, penicillin $(50 \mathrm{IU} / \mathrm{ml})$, streptomycin $(50 \mathrm{mcg} / \mathrm{ml}), 5 \%$ donor calf serum and bovine TSH $(1 \mathrm{mU} / \mathrm{ml})$ in $5 \% \mathrm{CO}_{2}$ at $37^{\circ} \mathrm{C}$ in a humidified incubator until confluent (6). The medium was replaced with fresh medium every $2-$ 3 days. For individual experiments, the cells were grown in full medium $(6 \mathrm{H})$ or in medium without TSH $(5 \mathrm{H})$. Cells were subpassaged using trypsin-collagenase and plated at the appropriate cell densities for the experiments described below. All experiments described below used cells from the 16 th to the 26 th passages, during which they were routinely monitored for cAMP production and iodide uptake in response to TSH.

CHO cells (JP26, JPO2) Chinese hamster ovary (CHO) cells which have been transfected with the human TSH receptor and the neomycin resistance gene (9) are widely used to measure TSH receptor antibodies in human thyroid disease. These cells were a gift from Dr G Vassart, Brussels, Belgium. JP26 are the CHO cells transfected with the human TSH receptor and the neomycin resistance gene, the JP02 cells have been transfected with the neomycin resistance gene alone and are used as the control cells, therefore all experiments were done in parallel using both JP26 and JPO2 cells. The use of the CHO JP26 cell line will determine if the effects of AMD on the rat TSH receptor/ adenylate cyclase are also seen in the human TSH receptor/adenylate cyclase machinery.

JP26 and JP02 cells were routinely cultured in $75 \mathrm{~cm}^{2}$ flasks in Ham's F12 medium containing 10\% donor calf serum, sodium pyruvate $(10 \mu \mathrm{g} / \mathrm{ml})$, penicillin $(100 \mathrm{IU} / \mathrm{ml})$, streptomycin $(100 \mathrm{mcg} / \mathrm{ml})$ and geneticin $(\mathrm{G} 418,400 \mu \mathrm{g} / \mathrm{ml})$ in $5 \% \mathrm{CO}_{2}$ at $37^{\circ} \mathrm{C}$ in a humidified incubator until confluent. The medium was replaced with fresh medium every 2 days. Cells were subpassaged using $0.1 \%$ trypsin and plated at the appropriate cell densities for the functional experiments described below. This study used JP26 cells from the 23rd to the 25 th passages and JP02 cells from the 17th to the 19th passages.

\section{TSH-stimulated cAMP production bioassay in FRTL-5 cells}

Day 1 FRTL- 5 cells $\left(1 \times 10^{5}\right.$ cells $\left./ \mathrm{ml}\right)$ were seeded into 24-well plates and allowed to grow in $6 \mathrm{H}$ medium for 7 days. Cells were then washed and incubated in $5 \mathrm{H}$ medium (medium without TSH) for a further 3 days to sensitize cells to TSH. cAMP bioassay was then performed. Medium was removed and $100 \mu \mathrm{l}$ hypotonic Hank's buffer (10), $50 \mu \mathrm{l} 3 \mathrm{mmol} / \mathrm{l}$ 3-isobutyl-L-methylxanthine (IMX) and $150 \mu \mathrm{l}$ test substance added. Test substances were all made up in hypotonic Hank's buffer containing TSH $(10 \mathrm{mU} / \mathrm{ml})$. Substances tested were $\operatorname{AMD}(0,25,100,250$ and $500 \mu \mathrm{mol} / \mathrm{l}), \mathrm{NaI}(0,0.1,1$, 10 and $100 \mathrm{mmol} / \mathrm{l})$ or $\mathrm{TSH}(10 \mathrm{mU} / \mathrm{ml})$ alone in hypotonic Hank's buffer as the control. Plates were then incubated for $3 \mathrm{~h}$ at $37^{\circ} \mathrm{C}$. Supernatant was removed, snap-frozen in liquid nitrogen and stored at $-70^{\circ} \mathrm{C}$ until assayed for cAMP content using a cAMP $\left(\mathrm{I}^{125}\right)$ assay kit.

\section{TSH-stimulated cAMP production bioassay in CHO cells}

The advantage of the $\mathrm{CHO}$ cells is that they grow at a faster rate than the FRTL- 5 cells and do not require TSH for growth. Day $1 \mathrm{CHO}$ cells $\left(0.3 \times 10^{5}\right.$ cells $\left./ \mathrm{ml}\right)$ were seeded into 24-well plates and allowed to grow in growth medium. Day 3 cAMP bioassay was performed as in the FRTL- 5 cell experiments above.

\section{Washout studies for FRTL-5 and CHO cells}

Cells were preincubated with $\operatorname{AMD}(0,25,100,250$ and $500 \mu \mathrm{mol} / \mathrm{l})$ or $\mathrm{NaI}(0,0.1,1,10$ and $100 \mathrm{mmol} / \mathrm{l})$ for $3 \mathrm{~h}$ after which medium was aspirated and cells were washed twice with $0.5 \mathrm{ml} 0.15 \mathrm{~mol} / \mathrm{l}$ PBS. Then $150 \mu \mathrm{l}$ TSH $(10 \mathrm{mU} / \mathrm{ml}), 100 \mu \mathrm{l}$ hypotonic Hank's buffer and $50 \mu \mathrm{l} 3 \mathrm{mmol} / \mathrm{l}$ IMX were added to wells and incubated for $3 \mathrm{~h}$ as above. Supernatant was collected, frozen and stored until assayed for cAMP as above.

\section{Forskolin- and cholera toxin (CT)-stimulated cAMP production bioassay in FRTL-5 and CHO cells}

A cAMP bioassay was performed as above using $100 \mu \mathrm{mol} / \mathrm{l}$ forskolin, $1.5 \mathrm{mg} / \mathrm{ml} \mathrm{CT,} 250 \mu \mathrm{mol} / \mathrm{l} \mathrm{AMD}$, $100 \mathrm{mmol} / \mathrm{l} \mathrm{NaI}, 1 \mathrm{~mol} / \mathrm{l} \mathrm{NaI}$ and $10 \mathrm{mU} / \mathrm{ml} \mathrm{TSH}$ tested either alone or in combinations of two or more test substances. After a 3-h incubation the supernatant was collected, frozen and stored until assayed for cAMP as above. 


\section{Statistical analysis}

Results are expressed as the mean \pm s.e. of three to six experiments. Analysis of difference amongst multiple groups was performed using analysis of variance (ANOVA), followed by Fisher PLSD or Scheffe's F-test for the significance of differences between the groups at a significance level of $95 \%$. Analysis of difference in two group samples was performed by using Mann-Whitney U nonparametric test at a significance level of $95 \%$.

\section{Materials}

Coons' modified Ham's F-12 medium, Ham's F-12 medium, insulin, hydrocortisone, transferrin, somatostatin, glycyl-L-histidyl-L-lysine acetate, bovine TSH, penicillin/streptomycin, IMX, sodium pyruvate, geneticin (G418), forskolin, CT, NaI and AMD were all obtained from Sigma, Sydney, Australia. Calf serum was obtained from Cytosystems, Sydney, Australia. Nonessential amino acid mixture was obtained from Commonwealth Serum Laboratories, Sydney, Australia. cAMP $\left(\mathrm{I}^{125}\right)$ assay kit was obtained from Amersham Australia Pty Ltd, Sydney, Australia.

\section{Results}

\section{Effects of TSH on cAMP production in FRTL-5 cells and CHO cells}

In order to determine the functional activity of FRTL-5 cells and secondly to determine the maximum doseresponse of cAMP to TSH, cells were exposed to log order increases in TSH concentration $(0,0.01,0.1,1,10$ and $100 \mathrm{mU} / \mathrm{ml}$ ). Experiments were performed on separate 24-well plates with each plate being exposed to a different TSH concentration. Twenty-one wells were used for cAMP estimation whilst three wells were used for protein estimation. Results are expressed as pmol $\mathrm{cAMP} / \mathrm{mg}$ protein.

There was an increase in the production of cAMP with increasing concentrations of TSH. The concentration of cAMP rose rapidly from baseline values (no $\mathrm{TSH}=100 \pm 2 \mathrm{pmol} / \mathrm{mg}$ protein) to reach a plateau at concentrations above $1 \mathrm{mU} / \mathrm{ml}$ TSH $(3465 \pm 90 \mathrm{pmol} /$ mg protein, $P<0.05)$, with maximal stimulation of cAMP production at $10 \mathrm{mU} / \mathrm{ml} \mathrm{TSH}(3785 \pm 100 \mathrm{pmol} /$ mg protein). Because experiments were designed to assess inhibition of TSH-stimulated cAMP production we chose a concentration of $10 \mathrm{mU} / \mathrm{ml} \mathrm{TSH}$ as the FRTL-5 stimulant.

Similar experiments were conducted in JP26 CHO cells. There was an increase in cAMP production from baseline, no $\mathrm{TSH}=105 \pm 2 \mathrm{pmol} / \mathrm{mg}$ protein to $1395 \pm$ $121 \mathrm{pmol} / \mathrm{mg}$ protein at $10 \mathrm{mU} / \mathrm{ml} \mathrm{TSH}(P<0.05)$ and $2395 \pm 180 \mathrm{pmol} / \mathrm{mg}$ protein at $100 \mathrm{mU} / \mathrm{ml} \mathrm{TSH}$ $(P<0.05)$. To be consistent with the FRTL-5 cell experiments we used $10 \mathrm{mU} / \mathrm{ml}$ TSH as our cAMP stimulant in the JP26 CHO cells. The control cells, JPO2 CHO cells, showed no significant TSH-stimulated cAMP activity at $10 \mathrm{mU} / \mathrm{ml}$ TSH $(45 \pm 1 \mathrm{pmol} / \mathrm{mg}$ protein) from baseline (no $\mathrm{TSH}=50 \pm 3 \mathrm{pmol} / \mathrm{mg}$ protein) as expected. TSH at $100 \mathrm{mU} / \mathrm{ml}(99 \pm 8 \mathrm{pmol} / \mathrm{mg}$ protein) produced a slight response in the JPO2 control cells which may be attributed to TSH cross-reactivity with luteinizing hormone and follicle-stimulating hormone receptors.

\section{Comparison of the effects of AMD and iodide on TSH-stimulated cAMP production}

In order to determine the effects of AMD on TSHstimulated cAMP production in FRTL-5 cells, cells were exposed to increasing concentrations of AMD $(0-500 \mu \mathrm{mol} / \mathrm{l}$ AMD) in the presence of $10 \mathrm{mU} / \mathrm{ml} \mathrm{TSH}$. AMD did not inhibit cAMP production at concentrations of less than $100 \mu \mathrm{mol} / \mathrm{l}$ (equivalent to $200 \mu \mathrm{mol} / \mathrm{l}$ iodide). Above $100 \mu \mathrm{mol} / \mathrm{l}$ AMD there was a decline in cAMP production from baseline $(\mathrm{AMD}=0 \mu \mathrm{mol} / \mathrm{l}$, $\mathrm{TSH}=10 \mathrm{mU} / \mathrm{ml}$ ). At concentrations greater than $100 \mu \mathrm{mol} / \mathrm{l}$ AMD there was a fall in cAMP production to $82 \%$ of baseline values. cAMP production continued to fall reaching $37 \%$ of baseline values at concentrations of $500 \mu \mathrm{mol} / \mathrm{l}$ AMD ( $P=0.0001$, ANOVA).

To ascertain whether the observed effects were due to the iodine content of AMD, FRTL-5 cells were exposed to increasing concentrations of $\mathrm{NaI}(0-100 \mathrm{mmol} / \mathrm{l})$. By comparison to AMD, equivalent doses of inorganic iodide had negligible effects on cAMP production, until supraphysiological doses were used (Fig. 1).

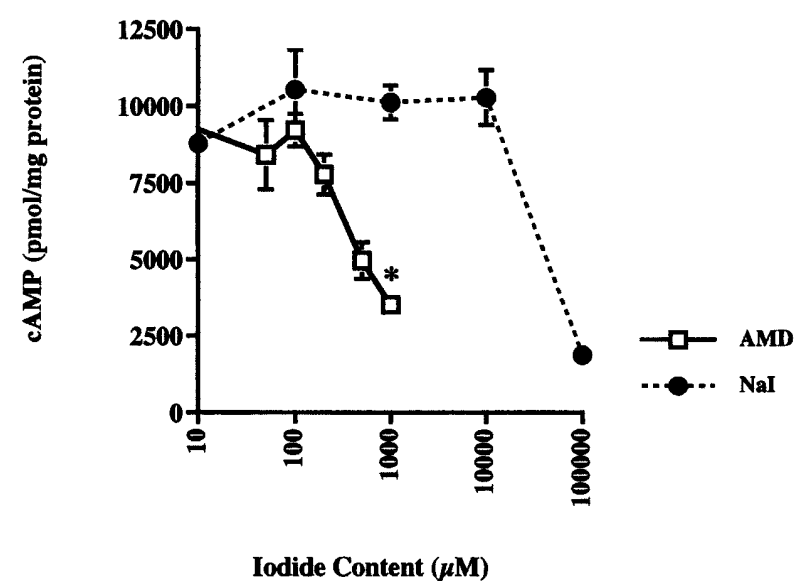

Figure 1 The inhibitory effects of AMD and Nal on cAMP production in FRTL-5 cells. AMD inhibited TSH-stimulated cAMP production at a much lower iodide content $(1000 \mu \mathrm{mol} / \mathrm{l})$ than in the Nal-treated cells. Nal levels above $10000 \mu \mathrm{mol} / \mathrm{l}$ were required to achieve inhibition similar to that seen at $500 \mu \mathrm{mol} / / \mathrm{AMD}$ (equivalent to $1000 \mu \mathrm{mol} / /$ iodide). ${ }^{*} P<0.05$, Mann-Whitney U nonparametric test at iodide concentration of $1000 \mu \mathrm{mol} / \mathrm{l}$. 


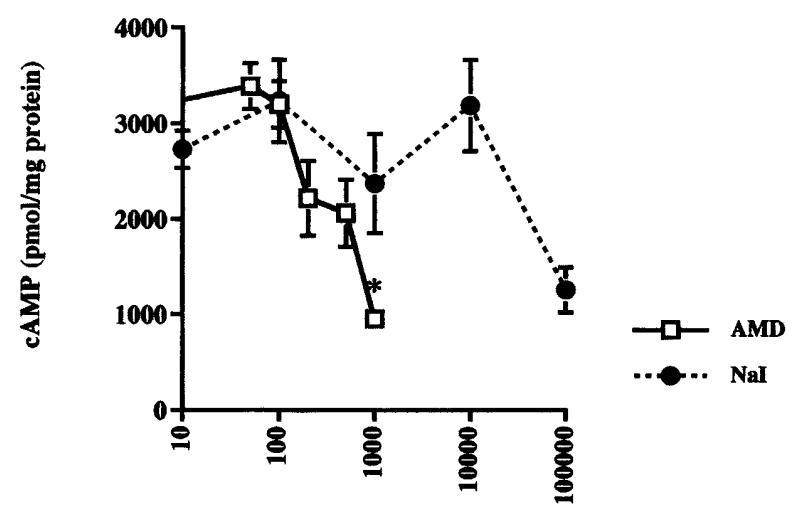

Iodide Content $(\boldsymbol{\mu M})$

Figure 2 The inhibitory effects of AMD and Nal on cAMP production in JP26 CHO cells. Similar to the FRTL- 5 cell experiments AMD inhibited TSH-stimulated CAMP production at a much lower iodide content $(1000 \mu \mathrm{mol} / \mathrm{l})$ than in the Nal-treated cells. Nal levels above $10000 \mu \mathrm{mol} / /$ were required to achieve inhibition similar to that seen at $500 \mu \mathrm{mol} / \mathrm{I}$ AMD (equivalent to $1000 \mu \mathrm{mol} / /$ iodide). ${ }^{*} P<0.05$, Mann-Whitney $U$ nonparametric test at iodide concentration of $1000 \mu \mathrm{mol} / \mathrm{l}$

The effects in the JP26 cells were similar to those observed in the FRTL-5 cell line, AMD did not inhibit cAMP production at concentrations of less than $100 \mu \mathrm{mol} / \mathrm{l}$ AMD. There was a decline in TSH-stimulated cAMP production from baseline to $59 \%$ at $100 \mu \mathrm{mol} / \mathrm{l} \mathrm{AMD}$ and to $25 \%$ of baseline at $500 \mu \mathrm{mol} /$ l AMD $(P=<0.05$, ANOVA). Similar to the FRTL-5 cells, inorganic iodide alone had no effect on TSH-stimulated cAMP production within the physiological dose range (Fig. 2). The JP02 CHO control cells as expected showed no response to TSH stimulation with AMD or NaI and gave a flat response (results not shown).

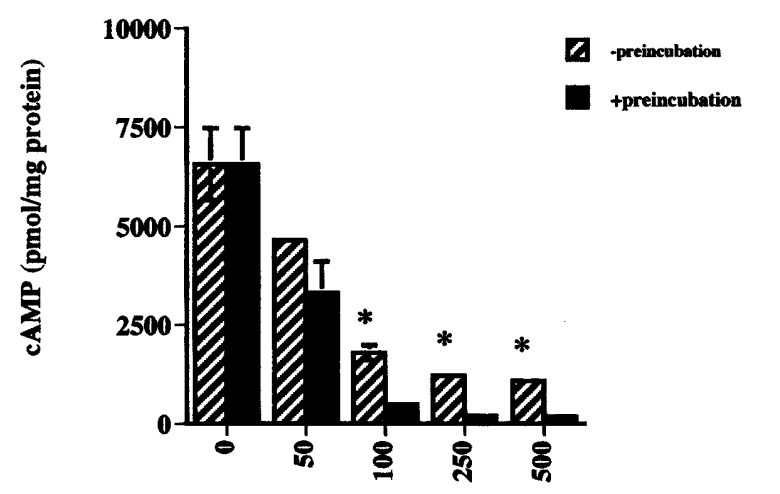

AMD ( $\boldsymbol{\mu} \mathbf{M})$

Figure 3 Washout studies using AMD in FRTL-5 cells. Preincubating FRTL-5 cells in AMD with removal of AMD prior to adding TSH resulted in an even greater inhibition of TSH-stimulated CAMP production indicating an irreversible effect of AMD. * =significantly different from matching preincubation dose, $P<0.05$, MannWhitney U nonparametric test.

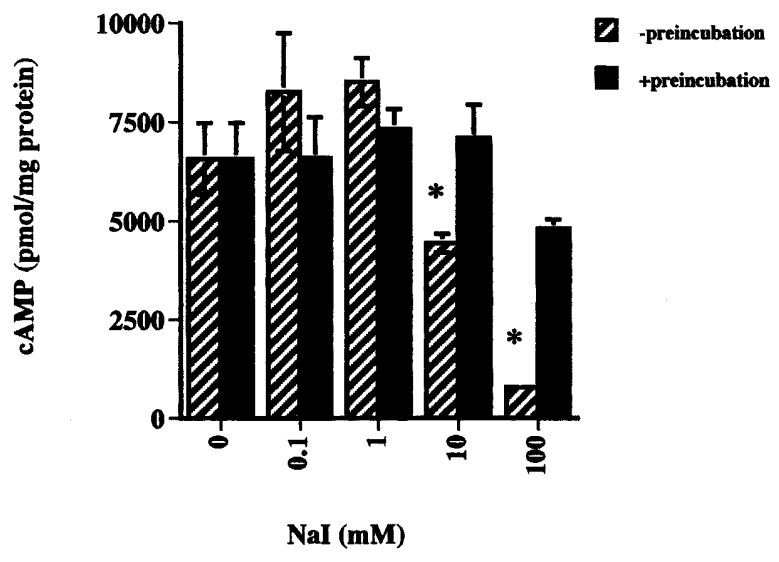

Figure 4 Washout studies using Nal in FRTL- 5 cells. Preincubating FRTL-5 cells in Nal with removal of Nal prior to adding TSH resulted in restoration of cAMP production indicating that the inhibitory effects of $\mathrm{Nal}$ are reversible. ${ }^{*}=$ significantly different from matching preincubation dose, $P<0.05$, Mann-Whitney $U$ nonparametric test.

\section{Washout studies}

As a measure of iodine bioavailability, we examined the reversibility of the inhibitory effects of both AMD and $\mathrm{NaI}$ on TSH-stimulated cAMP production by preincubating FRTL-5 cells with increasing concentrations of AMD or NaI. We found that preincubation with AMD caused a greater inhibition of cAMP production than cells not preincubated with AMD. Preincubation with AMD decreased TSH-stimulated cAMP production to $7 \%$ of baseline values at $100 \mu \mathrm{mol} / \mathrm{l}$ AMD, compared with $25 \%$ of baseline values in the non-preincubated group ( $P=0.0001$, ANOVA) (Fig. 3). These effects were not altered by washout and the inhibitory effect was persistent. By comparison, preincubation of FRTL 5 cells with $\mathrm{NaI}$ and its subsequent washout completely removed the partial inhibitory effects of $\mathrm{NaI}$ (see Fig. 4).

In a similar experiment to the FRTL-5 cells, we preincubated JP26 and JP02 $\mathrm{CHO}$ cells with increasing concentrations of AMD or NaI to determine if similar effects are seen in the human TSH receptor/adenylate cyclase machinery. Analogous to the FRTL-5 experiments, we found that preincubation with AMD caused greater inhibition of TSH-stimulated cAMP production at all concentrations (Fig. 5). Unlike the FRTL-5 experiments preincubation with $\mathrm{NaI}$ had a greater inhibitory effect on cAMP production in the JP26 CHO cells though not to the extent of AMD (Fig. 6). This difference is probably explained by the lack of a $\mathrm{Na}^{+} / \mathrm{I}^{-}$ symporter. The control cells JP02 had no activity (results not shown).

\section{Comparison of the effects of AMD and NaI on forskolin-stimulated cAMP production}

Forskolin stimulates the cAMP cascade at the catalytic component of adenylate cyclase (11). The use of 


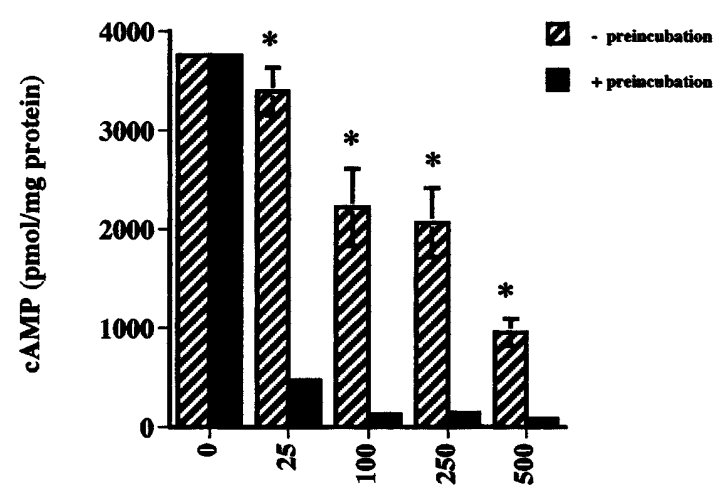

AMD ( $\boldsymbol{\mu M})$

Figure 5 Washout studies using AMD in JP26 CHO cells. Similar to the FRTL- 5 cell experiment, preincubating JP26 cells in AMD with removal of AMD prior to adding TSH resulted in an even greater inhibition of TSH-stimulated CAMP production indicating an irreversible effect of AMD. * =significantly different from matching preincubation dose, $P<0.05$, Mann-Whitney U nonparametric test.

forskolin allowed us to determine whether the inhibitory effects of AMD were above or below the adenylate cyclase in cAMP cascade. Figures 7 and 8 describe the results of various combinations of forskolin, TSH, AMD and NaI in FRTL- 5 cells and CHO cells (JP26 and JP02). The addition of forskolin to the AMD and TSH combination was able to partially restore cAMP production in the FRTL-5, JP26 and JP02 CHO cell lines, indicating that AMD may affect the interaction of the receptor with the $\mathrm{G}$ proteins and adenylate cyclase. The observation that this effect was also seen in the

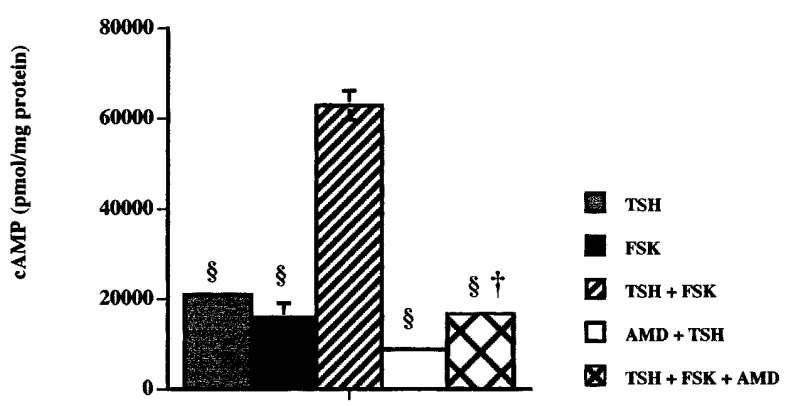

FRTL-5

Figure 7 The effects of AMD on forskolin (FSK)-and TSH stimulated CAMP production in FRTL-5 cells. The addition of forskolin to AMD and TSH in FRTL-5 cells only partially restored cAMP production indicating an effect on the interaction between the TSH receptor, $G$ proteins and adenylate cyclase. $\S=$ significantly different from TSH and forskolin, ANOVA, Fisher PLSD, $P<0.05$. $\dagger=$ significantly different from AMD and TSH, ANOVA, Fisher PLSD, $P<0.05$.

control JP02 cells indicates that this may be the case because although these cells lack the TSH receptor they do have adenylate cyclase and G proteins associated with other receptors present in that cell line. Reinforcing this interactive property with membrane proteins is the observation that cAMP stimulation with forskolin alone was much greater than with AMD and forskolin together in the all the cell lines (results not shown).

In FRTL-5 cells exposed to $100 \mathrm{mmol} / \mathrm{l} \mathrm{NaI}$, the addition of forskolin was able to completely restore cAMP production. Similar experiments using $100 \mathrm{mmol} / \mathrm{l} \mathrm{NaI}$ in JP2 6 CHO cells also showed complete restoration of cAMP production when forskolin was

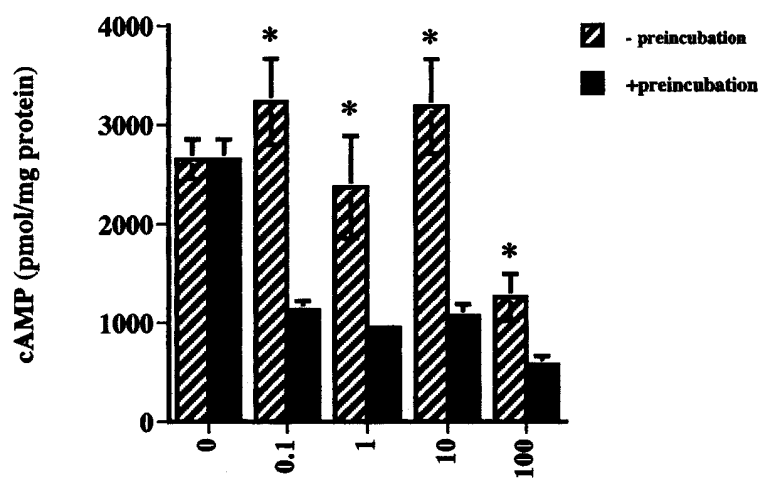

NaI (mM)

Figure 6 Washout studies using Nal in JP26 CHO cells. Unlike the FRTL- 5 cell experiment, preincubating JP26 cells in Nal with removal of Nal prior to adding TSH resulted in only partial restoration of CAMP production indicating partial reversibility of the inhibitory effects of $\mathrm{Nal}$ in this cell line. The reason for this may be the lack of the $\mathrm{Na}^{+} / \mathrm{I}^{-}$symporter in the JP26 $\mathrm{CHO}$ cells.

${ }^{*}=$ significantly different from matching preincubation dose, $P<0.05$, Mann-Whitney U nonparametric test.

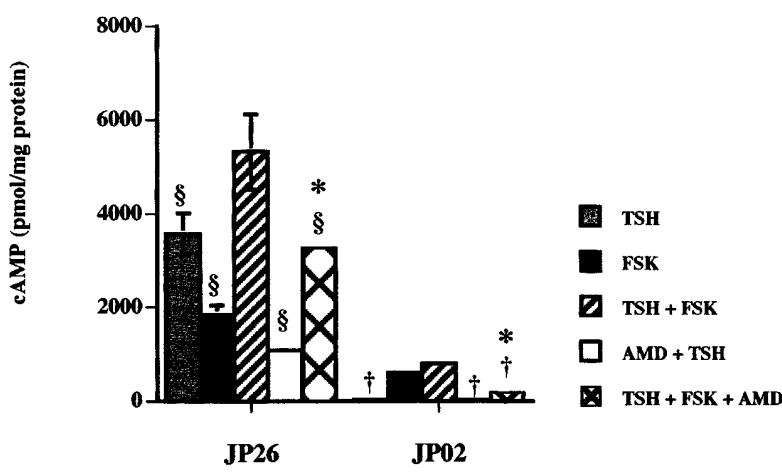

Figure 8 The effects of AMD on forskolin (FSK)- and TSHstimulated cAMP production in JP26 and JP02 CHO cells. Similar to the FRTL-5 cell experiments the addition of forskolin to AMD and TSH in JP26 and JP02 cells only partially restored cAMP production indicating an effect on the interaction between the receptor, $G$ proteins and adenylate cyclase. $\S=$ significantly different from TSH and forskolin, ANOVA, Fisher PLSD, $P<0.05$ in JP26 cells.

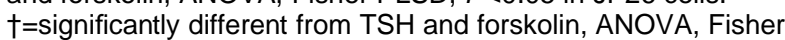
PLSD, $P<0.05$ in JP02 $\mathrm{CHO}$ cells. * $=$ significantly different from AMD and TSH, ANOVA, Fisher PLSD, $P<0.05$ in both JP26 and JP02 $\mathrm{CHO}$ cells. 
introduced into the system (results not shown). However, experiments using $1 \mathrm{~mol} / \mathrm{l} \mathrm{NaI}$ concentration in both FRTL-5 and JP26 cell lines showed that forskolin only partially restored cAMP production in the presence of TSH (results not shown).

\section{Comparison of the effects of AMD and NaI on CT-stimulated cAMP production}

The TSH receptor associates with $\mathrm{G}$ proteins which in turn associate with adenylate cyclase to stimulate cAMP production. CT stimulates the stimulatory adenylate cyclase $\mathrm{G}$ protein $\left(\mathrm{G}_{\mathrm{s}}\right)$. The use of $\mathrm{CT}$ allowed us to determine whether the inhibitory effects of AMD were above or below the $\mathrm{G}$ proteins in the cAMP cascade. Figures 9 and 10 show the results of various combinations of CT, TSH, AMD and NaI in FRTL-5 and CHO cells (JP26 and JP02). In FRTL-5 cells, the addition of CT to the AMD and TSH combination did not increase cAMP production at all indicating a direct affect on the coupling of the $\mathrm{G}_{\mathrm{s}}$ protein with adenylate cyclase. Similarly the addition of CT to the AMD and TSH combination in the JP26 cell line did not increase cAMP production at all. This effect was also seen in the control JP02 cells indicating that AMD affects the interactions of receptor and the $\mathrm{G}$ proteins.

In similar experiments using $100 \mathrm{mmol} / \mathrm{l} \mathrm{NaI}$, there was a complete restoration of cAMP production in the FRTL-5 and JP26 CHO cells when CT was introduced into the system, indicating that at this concentration $\mathrm{NaI}$ was not affecting the receptor and $\mathrm{G}$ protein interaction (results not shown). However, experiments using $1 \mathrm{~mol} / \mathrm{l} \mathrm{NaI}$ concentration in the presence of TSH showed that CT did not restore cAMP production in FRTL-5 cells, JP26 and JP02 cells. This may indicate that at very high levels of iodide the interaction of the TSH receptor, G proteins and adenylate cyclase may be affected.

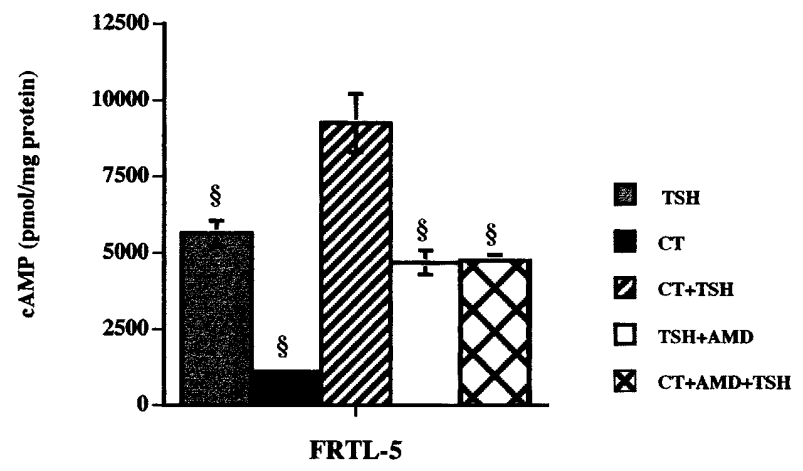

Figure 9 The effects of AMD on CT- and TSH-stimulated CAMP production in FRTL- 5 cells. The addition of CT to AMD and TSH in FRTL-5 cells did not restore cAMP production indicating an effect on the coupling of the TSH receptor and the $\mathrm{G}_{\mathrm{S}}$ protein.

$\S=$ significantly different from CT and TSH, ANOVA, Fisher PLSD, $P<0.05$

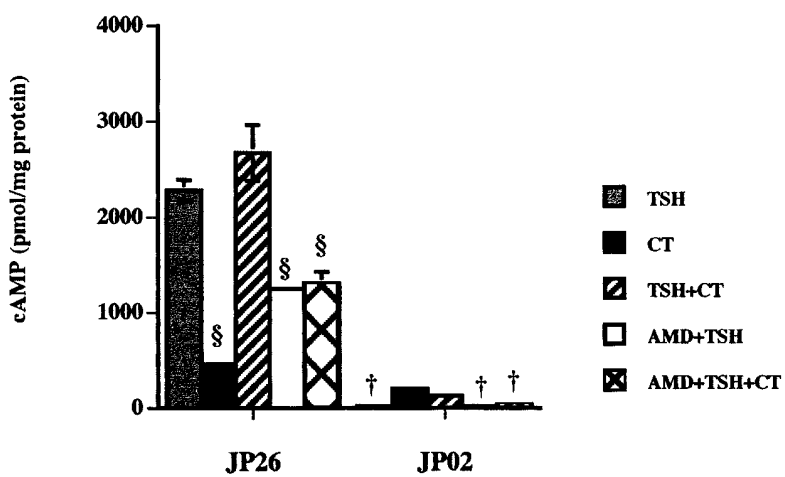

Figure 10 The effects of AMD on CT- and TSH-stimulated cAMP production in JP26 and JP02 CHO cells. Similar to the FRTL-5 cell experiments the addition of CT to AMD and TSH in JP26 and JP02 cells did not restore cAMP production indicating an effect on the coupling of the receptor and the $\mathrm{G}_{\mathrm{s}}$ protein. $\S=$ significantly different from CT and TSH, ANOVA, Fisher PLSD, $P<0.05$ in JP26 cells. $\dagger=$ significantly different from CT and TSH, ANOVA, Fisher PLSD, $P<0.05$ in JP02 cells.

\section{Discussion}

The role of iodine versus direct drug toxicity of AMD in the pathogenesis of thyroid dysfunction and damage has been a long-standing debate. The high iodine content of the drug and its structural resemblance to thyroid hormone (1) are generally the focal point in the attempt to establish a cause for the effects of the drug. The two atoms of iodine per AMD molecule in a $200 \mathrm{mg}$ tablet results in an iodine intake of approximately 40 times the average daily requirement (2). Our data indicate that at equimolar concentrations of iodide, AMD has potent and persistent inhibitory effects on thyroid cell function in vitro. At lower concentrations of iodide, AMD exerts a significant inhibition of function compared with the equivalent amount of $\mathrm{NaI}$ in both cell lines (FRTL-5 and CHO-JP26). At higher concentrations of $\mathrm{NaI}(100 \mathrm{mmol} / \mathrm{l}=100000 \mu \mathrm{mol} / \mathrm{l}$ iodide $)$ the effects are similar to those seen at the lower iodide equivalent AMD concentration $(100 \mu \mathrm{mol} / \mathrm{l}$ AMD $=$ $200 \mu \mathrm{mol} / \mathrm{l}$ iodide). Where AMD and iodine (at high levels) have the ability to disturb signal transduction through G protein-associated receptors, our data indicate that the iodine content of AMD alone is not the sole explanation for the observed inhibitory effects on thyroid cell function.

Under normal circumstances the thyroid gland adapts to an increased iodine load by autoregulation of iodide uptake and clearance. AMD exposure in humans reduces thyroid iodide uptake as well as the thyroid clearance of iodide (12). Further there is an increase in both urinary iodide and plasma iodide resulting in an increase in absolute iodide uptake. The net result is a massive increase in available inorganic iodide during treatment. The decrease in thyroid iodide clearance is an adaptive mechanism that allows 'escape' from the Wolff-Chaikoff effect (13). This allows 
restoration of more efficient organification despite continuing high plasma inorganic iodide and is mediated by inhibition of iodide transport until intrathyroidal iodine concentrations fall below the critical level needed to sustain the Wolff-Chaikoff effect (14). Thyroid autoimmunity, a common component of AIH, may be the necessary prerequisite that determines those patients who will fail to escape from the excess iodine load and develop AIH by interfering with organification.

Differences in iodine pharmacokinetics and bioavailability are mechanisms that may account for the potent and persistent effects of AMD compared with inorganic iodine. Whereas NaI pre-exposure was readily reversed by a change in the cell culture media, AMD effects on thyroid cell function persisted after removal of the drug. In support of these observations Rani (5) found that the inhibitory effects on function of AMD in dog thyroid cells were dependent on the cell being intact. In membrane preparations the effects of AMD were reversible whereas these effects were irreversible in the intact dog thyroid cells. These results reflect the long half-life of the drug. Terminal elimination half-life studies of AMD in patient groups have shown that the half-life can vary from 8 to 107 days (15) and is attributed to the amphiphilic nature of the drug. These compounds are known to interact with lipids forming indigestible complexes, stored in intracellular lysosomes $(16,17)$. Conversion to the more toxic metabolite, desethylamiodarone, may also explain the prolonged action of the drug (18).

Analytical ion microscopy studies in mice have shown that bioavailability of iodide released from AMD is different from that released from NaI (19). Under normal conditions free iodide is not detected in the thyroid, however in AMD-treated patients, trapped iodide is built up in the thyroid presumably because organic binding of iodide becomes the rate-limiting step of intrathyroidal iodine metabolism. A threefold increase of the percentage of radioiodide discharged after perchlorate administration has been described in patients receiving long-term AMD therapy (20). X-ray fluorescence (21) and computerized tomography (22) have shown that AMD increases intrathyroidal iodide by a factor of four in patients remaining euthyroid. The constant iodide release from AMD may result either in a failure to escape from the Wolff-Chaikoff effect or may precipitate iodide toxicity $(20,23)$.

This then brings us back to the question of iodide presentation during AMD treatment. The intrathyroidal iodide during AMD treatment remains high even though iodide transport has ceased. AMD has been estimated to release $10 \%$ of its total iodide at any one time (12). This means that the intrathyroidal iodide cannot be controlled by simply ceasing iodide transport, assuming AMD enters the cell through a different path and once inside the cell AMD will continually release iodide as well as exert its own toxic effects. Moreover in vivo, a small to moderate dose of AMD over an extended period of time may result in a large accumulation of the drug in the tissue consistent with high iodine content described in X-ray fluorescence (21) and computerized tomography (22) studies. Thus the higher doses of AMD and NaI used in this study may more appropriately reflect what is occurring during long-term AMD treatment in vivo. Our previous studies showed that AMD induced different changes to thyroid ultrastructure compared with an iodide equivalent (24). The results from this study indicate that AMD exerted its own specific toxic effects on the thyroid which may be a combination of the excess iodide release and drug toxicity. Others have demonstrated iodide toxicity leading to inhibition of TSH-induced cAMP production in a number of thyroid cell lines $(11,25-28)$. Others have shown iodide toxicity leading to necrosis and thyroid atrophy in iodine-deficient animal models (2931). This effect was also seen in isolated human thyroid follicles (32). The mechanism for this thyroid cell destruction is not known but it is postulated to involve the formation of secondary lysosomes and free radical attack and lipid peroxidation (32-34).

In this study, we also used a non-thyroid cell line transfected with the human TSH receptor to ascertain whether the effects of AMD were possibly via the TSH receptor. AMD affected both FRTL-5 and JP26 CHO cell lines in a similar fashion indicating possible TSH receptor involvement which would also contribute to the inhibitory effects observed. Rani (5) in 1990 performed ${ }^{125} \mathrm{I}$-TSH binding studies in cultured dog thyroid cells. This study showed that there was an increase in specific binding of ${ }^{125} \mathrm{I}$-TSH with as little as $10 \mu \mathrm{mol} / \mathrm{l}$ AMD and this became progressively greater as AMD concentration increased reaching a plateau at $100 \mu \mathrm{mol} / \mathrm{l}$ AMD. The time-course study revealed an increase in labelled TSH binding as time progressed reaching a plateau at $60 \mathrm{~min}$. This is opposite to that which is observed in functional studies where cAMP production decreases as AMD concentration increases. This may indicate that the drug affects the receptors in such a way that receptor synthesis is increased to try to counterbalance the toxic effects of the drug. The amphiphilic nature of AMD may be the key to this effect since small quantities of AMD have been observed to inhibit the equilibrium binding of the muscarinic ligand to its receptors in purified canine cardiac sarcolemmal vesicles. It may be that AMD and/or its metabolite, desethylamiodarone, modulates ligand binding to the muscarinic receptor by influencing lipid-protein interactions (35), then, it is possible that AMD affects lipid-protein interactions of the TSH receptor resulting in disruption of signal transduction. A study into the effects of amphiphilic drugs on the internalization of CT showed that these drugs inhibit vesicular transport of $\mathrm{CT}$ to the Golgi apparatus in hippocampal neurones and consequently inhibited the ability of CT to elevate cAMP (36). In our study CT was 
not able to restore cAMP production in the presence of TSH and AMD. High concentrations of $\mathrm{NaI}(1 \mathrm{~mol} / \mathrm{l})$ had similar effects indicating that constant iodide release over a period of time from AMD may affect the TSH receptor and $\mathrm{G}$ protein interaction in the cAMP cascade in a similar fashion.

Forskolin was able to partially overcome the inhibitory effects of AMD in both FRTL-5 and CHO cell lines. This indicates an effect on the cAMP cascade above the catalytic component of adenylate cyclase such as TSH receptor with the $\mathrm{G}$ proteins and adenylate cyclase. The reason for the blunted response may once again indicate that there is more than one factor involved in the observed effects. The inhibitory effects of NaI $(100 \mathrm{mmol} / \mathrm{l})$ were reversed by adding forskolin to the system, however at higher concentrations of $\mathrm{NaI}$ $(1 \mathrm{~mol} / \mathrm{l})$ the cAMP production was only partially restored in FRTL-5 and JP26 cells. These results indicate that AMD and very high iodide $(1 \mathrm{~mol} / \mathrm{l})$ affect the $\mathrm{G}_{\mathrm{s}}$ protein-adenylate cyclase interaction since addition of CT did not reverse the inhibitory effects.

Gathering all the available data on the effects of AMD such as inhibition of TSH-stimulated cAMP production (5), diminished thyroid hormone secretion (37) and iodine metabolism (38), the effects on peripheral thyroid hormone metabolism (39-41) and effects on thyroid hormone receptors (41) may provide a mechanism for the development of hypothyroidism in some patients receiving AMD (3). Additionally the effects of AMD on cell viability are also important. Chiovato et al. (2) showed that AMD in concentrations greater than or equal to $75 \mu \mathrm{mol} / \mathrm{l}$ were cytotoxic to FRTL-5 cells over a 24 -h period (2). In our own cell viability studies not shown here, trypan blue exclusion tests showed that AMD in concentrations of $50 \mu \mathrm{mol} / \mathrm{l}$ and above were cytotoxic to FRTL- 5 cells over a 48-h period. Under light microscope examination FRTL-5 cells exposed to $250 \mu \mathrm{mol} / \mathrm{l}$ AMD had lost their normal appearance with the outer cell membrane appearing fuzzy, almost jaggered in some cells. Examination of cells under the microscope at earlier time-points such as 3 and $6 \mathrm{~h}$ did not show any abnormal cell appearance perhaps indicating that an accumulation of $\mathrm{AMD}$ for a time greater that $6 \mathrm{~h}$ is required to induce the membrane changes observed. Similar experiments using NaI showed cytotoxicity to FRTL-5 cells at concentrations of $100 \mathrm{mmol} / \mathrm{l} \mathrm{NaI}$ with no apparent changes in cell morphology.

In conclusion, our results clearly showed a difference between the effects of AMD versus those of physiological doses of iodide. The inhibitory effects of AMD occurred at lower concentrations of iodide than those seen in the NaI-treated cells and this is probably related to a loss of iodine-controlled thyroid autoregulation with AMD treatment. The effects of AMD were irreversible indicating a possible persistence of the Wolff-Chaikoff effect due to a constant high intracellular iodide level. The inhibitory effects of AMD (also seen at supraphysiological doses of iodide) were partially overcome by forskolin but not by CT indicating an effect on TSH receptor interactions with the other signal transduction elements such as $\mathrm{G}$ proteins and adenylate cyclase. The persistence of the Wolff-Chaikoff effect through loss of autoregulation may be a mechanism of the observed hypothyroidism in some patients taking AMD. The combined effects of the constant release of iodide together with the drug toxicity may be the mechanism for these observations.

\section{References}

1 Plomp TA. Analytical profiles of amiodarone. In Analytical Profiles of Drug Substances, pp 1-120. Ed K Florey. San Diego: Academic Press Inc., 1991.

2 Chiovato L, Martino E, Tonacchera M, Santini F, Lapi P, Mammoli $\mathrm{C}$ et al. Studies on the in vitro cytotoxic effect of amiodarone. Endocrinology 1994134 2277-2282.

3 Martino E, Aghini-Lombardi F, Mariotti S, Bartalena L, Lenziardi M, Ceccarelli C et al. Amiodarone iodine-induced hypothyroidism: risk factors and follow-up in 28 cases. Clinical Endocrinology 1987 $26227-237$.

4 Trip M. Wiersinga W \& Plomp T. Incidence, predictability and pathogenesis of amiodarone-induced thyrotoxicosis and hypothyroidism. American Journal of Medicine 199191 507-511.

5 Rani CSS. Amiodarone effects on thyrotropin receptors and responses stimulated by thyrotropin and carbachol in cultured dog thyroid cells. Endocrinology 1990127 2930-2937.

6 Ambesi-Impiombato FS, Parks LAM \& Coon HG. Culture of hormone-dependent functional epithelial cells from rat thyroids. Proceedings of the National Academy of Sciences of the USA 198077 3455-3459.

7 Ambesi-Impiombato FS. The FRTL-5 cells, an in vitro thyroid system: introduction and development. In FRTL-5 Today, pp 3-7. Eds FS Ambesi-Impiombato \& H Perrild. Amsterdam: Elsevier Science Publishers BV, 1989.

8 Kohn L \& Valente W. FRTL-5 manual: a current guide. In FRTL-5 Today, pp 243-273. Eds FS Ambesi-Impiombato \& H Perrild. Amsterdam: Elsevier Science Publishers BV, 1989.

9 Perret J, Ludgate M, Libert F, Gerard C, Dumont J, Vassart G et al. Stable expression of the human TSH receptor in CHO cells and characterisation of differentially expressing clones. Biochemical and Biophysical Research Communications 1990171 1044-1050.

10 Kasagi K, Konishi J, Iida Y, Ikekubo K, Mori T, Kuma K et al. A new in vitro assay for thyroid stimulator using cultured thyroid cells: effects of sodium chloride on adenosine $3^{\prime}, 5^{\prime}$-monophosphate increase. Journal of Clinical Endocrinology and Metabolism 198254 $108-114$.

11 Filetti S \& Rapoport B. Evidence that organic iodide attenuates the adenosine $3^{\prime}, 5^{\prime}$-monophosphate response to thyrotropin stimulation in thyroid tissue by an action at or near the adenylate cyclase catalytic unit. Endocrinology 1983113 1608-1615.

12 Rao RH, McCready VR \& Spathis GS. Iodine kinetic studies during amiodarone treatment. Journal of Clinical Endocrinology and Metabolism 198662 563-568.

13 Braverman LE \& Ingbar SH. Changes in thyroidal function during adaptation to large doses of iodide. Journal of Clinical Investigation $1963421216-1231$.

14 Nagataki S, Shizume K \& Nakao K. Effect of chronic graded doses of iodide on thyroid hormone synthesis. Endocrinology 196679 667-674.

15 Mason JW. Drug therapy. Amiodarone. New England Journal of Medicine 1986316 455-466.

16 Poucell S, Ireton J, Valencia-Mayoral P, Downar E, Larratt L, Patterson J et al. Amiodarone-associated phospholipidosis and fibrosis of the liver. Gastroenterology $198486926-936$. 
17 Unger J, Lambert M, Jonckheer MH \& Denayer P. Amiodarone and the thyroid: pharmacological, toxic and therapeutic effects. Journal of Internal Medicine 1993233 435-443.

18 Beddows SA, Page SR, Taylor AH, McNerney R, Whitley GS, Johnstone AP et al. Cytotoxic effects of amiodarone and desethylamiodarone on human thyrocytes. Biochemical Pharmacology 198938 4397-4403.

19 Briancon C, Halpern S, Telenczak P \& Fragu P. Changes in ${ }^{127} \mathrm{I}$ mice thyroid follicle studied by analytical ion microscopy: a key for the comprehension of amiodarone-induced thyroid diseases. Endocrinology $19901271502-1509$.

20 Wiersinga WM, Touber JL, Trip MD \& Van Royen EA. Uninhibited thyroidal uptake of radioiodine despite iodine excess in amiodarone-induced hypothyroidism. Journal of Clinical Endocrinology and Metabolism 198663 485-491.

21 Leger AF, Fragu P, Rougier P, Laurent MF, Tubiana M \& Savoie JC. Thyroid iodine content measured by X-ray fluorescence in amiodarone-induced thyrotoxicosis: concise communication. Journal of Nuclear Medicine 198324 582-585.

22 Gheri R, Biagini C, Colagrande S, Cesarino G \& Serio M Application of computed tomographic scanning to predict the occurence of hypothyroidism in amiodarone treated patients. In The Thyroid Gland. Environment and Autoimmunity, pp 207-210. Eds H Drexhage, J de Vijlder \& W Wiersinga. Amsterdam: Elsevier Science Publishers BV, 1990.

23 Braverman L. Normal and abnormal responses to iodine: disorders of iodine excess. In The Thyroid, A Fundamental and Clinical Text, pp 528. Eds S Werner \& S Ingbar. Hagerstown: Harper and Row, 1978.

24 Pitsiavas V, Smerdely P, Li M \& Boyages S. Amiodarone induces a different pattern of ultrastructural change in the thyroid to iodine excess alone in both the $\mathrm{BB} / \mathrm{W}$ rat and the Wistar rat. European Journal of Endocrinology 1997137 89-98.

25 Rapoport B, West MN \& Ingbar SH. On the mechanism of inhibition by iodine of the thyroid adenylate cyclase response to thyrotropic hormone. Endocrinology 197699 11-22.

26 Van Sande J \& Dumont JE. Inhibition by iodide of the activation of the thyroid cyclic 3', 5'-AMP system. Endocrinology $197596781-$ 786.

27 Beere HM, Tomlinson S \& Bidey SP. Iodide autoregulation of functional and morphological differentiation events in the FRTL-5 rat thyroid cell strain. Journal of Endocrinology 1990124 19-25.

28 Smerdely P, Pitsiavas V \& Boyages S. Evidence that the inhibitory effects of iodide on thyroid cell proliferation are due to arrest of the cell cycle at GOG1 and G2 m phases. Endocrinology 1993133 2881-2888.

29 Many M-C, Denef J-F, Hamudi S \& Haumont S. Increased follicular heterogeneity in experimental colloid goiter produced by refeed- ing iodine excess after thyroid hyperplasia. Endocrinology 1986 $118637-644$.

30 Many M-C, Denef J-F, Hamudi S, Cornette C, Haumont S \& Beckers $\mathrm{C}$. Effects of iodide and thyroxine on iodine-deficient mouse thyroid: a morphological and functional study. Journal of Endocrinology $1986110203-210$.

31 Contempre B, Denef J-F, Dumont JE \& Many M-C. Selenium deficiency aggravates the necrotizing effects of a high iodide dose in iodine deficient rats. Endocrinology 1993132 1866-1868.

32 Many M-C, Mestdagh C, van den Hove M-F \& Denef J-F. In vitro study of acute toxic effects of high iodide doses in human thyroid follicles. Endocrinology $1992131621-630$.

33 Mahmoud I, Colin I, Many M-C \& Denef J-F. Direct toxic effect of iodide in excess on iodine-deficient thyroid glands: epithelial necrosis and inflammation associated with lipofuscin accumulation. Experimental and Molecular Pathology 198644 259-271.

34 Neve P, Starling JR, Golstein J \& Krupp PP. Effects of iodine intake on thyroid secondary lysosomes after subtotal thyroidectomy. Endocrinology 1988123 478-486.

35 Colvin R, Oibo J, Alten R, Tyler L \& Leek D. Interaction of amiodarone and desethylamiodarone with the cardiac muscarinic receptor in vitro. Journal of Molecular Cell Cardiology 198921 453-460.

36 Sofer A \& Futerman A. Cationic amphiphilic drugs inhibit the internalization of cholera toxin to the Golgi apparatus and the subsequent elevation of cyclic AMP. Journal of Biological Chemistry $199527012117-12122$.

37 Laurberg P. Amiodarone inhibits T4 and T3 secretion but does not affect T4 deiodination to T3 in perfused dog thyroid lobes. Thyroidology 19881 1-4.

38 Gluzman BE, Coleoni AH, Targovnik HM \& Niepomniszcze H. Effects of amiodarone on thyroid iodine metabolism in vitro. Acta Endocrinologica 197785 781-790.

39 Burger A, Dinichert D, Nicod P, Jenny M, Lemarchand-Beraud T \& Vallotton MB. Effect of amiodarone on serum triiodothyronine, reverse triiodothyronine, thyroxine and thyrotropin. Journal of Clinical Investigation 197658 255-259.

40 Kannan R, Chopra I, Ookhtens M \& Singh B. Effect of amiodarone on non-deiodinative pathway of thyroid hormone metabolism. Acta Endocrinologica 1990122 249-254.

41 Norman M \& Lavin T. Antagonism of thyroid hormone action by amiodarone in rat pituitary tumor cells. Journal of Clinical Investigation 198983 306-313.

Received 31 July 1998

Accepted 26 October 1998 